\title{
Hubungan faktor lingkungan fisik, sosial dan ekonomi dengan kejadian Tuberkulosis Paru di Kecamatan Tambang Kabupaten Kampar
}

\author{
Arizta Nanda Putri ${ }^{1}$, Zahtamal ${ }^{2}$, Zulkifli $^{3}$ \\ ${ }^{1}$ Magister Ilmu Lingkungan Pascasarjana Universitas Riau. \\ ${ }^{2}$ Dosen Fakultas Kedokteran Universitas Riau, Pekanbaru. \\ ${ }^{3}$ Dosen Fakultas Perikanan dan Kelautan Universitas Riau.
}

*Correspondent email : arizta.nada@yahoo.com

Diterima: 17 Februari 2021 | Disetujui: 28 Februari 2021 | Diterbitkan: 28 Februari 2021

\begin{abstract}
Pulmonary tuberculosis is an infectious disease caused by Mycobacterium tuberculosis which mostly attacks the lungs and can also attack other organs. Tuberculosis is transmitted by smear positive tuberculosis patients, Tuberculosis germs are transmitted through the air when the patient coughs and sneezes so that the germs spread in the air in the form of droplets (sputum sparks), so people can become infected if they inhale the droplet into the respiratory tract (Ministry of Health Republic of Indonesia, 2014 ). According to Achmadi (2010) risk factors for tuberculosis transmission are environmental and behavioral factors. Environmental factors include ventilation, occupancy density, temperature, lighting and humidity. Whereas behavioral factors include smoking, spitting or sputum in any place, coughing or sneezing not closing the mouth and habit of not opening the window. Based on the results of a survey in Indonesia by the Directorate General of Communicable Disease Eradication and Environmental Health (2011), the high incidence of pulmonary TB is caused by a lack of knowledge. Knowledge of tuberculosis sufferers will affect the attitude and behavior such as throwing up spit or sputum that can be carelessly a source of transmission for people around him. Prabu in Fitriani (2013) explained that family heads who have an income below the regional minimum wage (UMR) will consume foods with nutrient levels that are not in accordance with the needs of each family member so that they have an nutritional status that is lacking and will make it easier to contract infectious diseases including Lung TB. According to WHO the number of cases of tuberculosis is ranked above HIV / AIDS. In 2016 there were an estimated 10.4 million new cases of tuberculosis or 142 cases / 100,000 population, 60\% of new cases occurred in 6 (six) countries namely India, Indonesia, China, Nigeria, Pakistan and South Africa, and Indonesia ranked second (WHO Global Tuberculosis Report, 2017). Based on data on Indonesia's health profile in 2018 the number of tuberculosis cases in Indonesia in 2017 was 420,994 cases and increased in 2018 to reach 511,873 cases (Ministry of Health Republic of Indonesia, 2018). The number of pulmonary tuberculosis in Riau Province in 2018 is 11,135 cases (Ministry of Health of the Republic of Indonesia, 2018). Based on data on the health profile of Kampar Regency in 2017, tuberculosis is an environmentally-based direct infectious disease that ranks second with a total of 1,071 cases after diarrheal disease with a total of 1,076 cases. The number of positive AFB cases in 2017 in Kampar District reached 1071 cases, with the highest number of sufferers found in Tambang District, 78 cases. In 2018 the number of TB cases was 1079 cases, with the highest cases also occurring at the Tambang Health Center with a total of 67 cases and 43 new cases, followed by the Siak Hulu I Health Center with a total of 57 cases (Dinkes District Health Office, 2018). Based on this, this study aims to analyze and the risk of the relationship between the physical, social and economic environment with the incidence of pulmonary tuberculosis in Tambang District, Kampar Regency.
\end{abstract}

Keywords: lung tuberculosis; physical environment; social environment; economic environment

Tuberkulosis paru adalah penyakit menular yang disebabkan oleh kuman Mycobacterium tuberculosis yang sebagian besar menyerang paru juga dapat menyerang organ tubuh lainnya. Penyakit Tuberkulosis ditularkan oleh penderita Tuberkulosis BTA positif, kuman Tuberkulosis menular melalui udara pada saat penderita batuk dan bersin sehingga kuman menyebar di udara dalam bentuk droplet (percikan dahak), sehingga orang dapat terinfeksi apabila menghirup droplet tersebut ke dalam saluran pernafasan (Kemenkes RI, 2014). Menurut Achmadi (2010) faktor risiko penularan tuberkulosis adalah faktor lingkungan dan faktor perilaku. Faktor lingkungan meliputi ventilasi, kepadatan hunian, suhu, pencahayaan dan kelembaban. Sedangkan faktor perilaku meliputi kebiasaan merokok, meludah atau membuang dahak di sembarang tempat, batuk atau bersin tidak menutup mulut dan kebiasaan tidak 


\section{SEHATI}

Jurnal Kesehatan
Vol 1, No 1, Februari 2021, p. 6-15

e-ISSN : 2775-6963 | p-ISSN : 2775-6955

membuka jendela. Berdasarkan hasil survei di Indonesia oleh Ditjen Pemberantas Penyakit Menular dan Penyehatan Lingkungan (2011) tingginya angka kejadian TB paru salah satunya disebabkan oleh kurangnya tingkat pengetahuan. Pengetahuan penderita tuberkulosis akan berpengaruh terhadap sikap dan perilakunya seperti membuang ludah atau dahak yang sembarangan dapat menjadi sumber penular bagi orang disekelilingnya Prabu dalam Fitriani (2013) menjelaskan bahwa kepala keluarga yang mempunyai pendapatan di bawah upah minimum regional (UMR) akan mengonsumsi makanan dengan kadar gizi yang tidak sesuai dengan kebutuhan bagi setiap anggota keluarga sehingga mempunyai status gizi yang kurang dan akan memudahkan untuk terkena penyakit infeksi diantaranya TB Paru.

Menurut WHO angka kasus penyakit tuberkulosis menduduki peringkat di atas HIV/AIDS. Pada tahun 2016 diperkirakan terdapat 10,4 juta kasus baru tuberkulosis atau 142 kasus/100.000 populasi, sebesar $60 \%$ kasus baru terjadi di 6 (enam) negara yaitu India, Indonesia, China, Nigeria, Pakistan dan Afrika Selatan, dan Indonesia menduduki peringkat kedua (WHO Global Tuberculosis Report, 2017). Berdasarkan data profil kesehatan Indonesia Tahun 2018 jumlah kasus tuberkulosis di Indonesia pada tahun 2017 adalah sebanyak 420.994 kasus dan meningkat pada tahun 2018 mencapai angka 511.873 kasus (Kemenkes RI, 2018). Angka tuberkulosis paru di Provinsi Riau pada Tahun 2018 adalah sebanyak 11.135 kasus (Kemenkes RI, 2018). Berdasarkan data profil kesehatan Kabupaten Kampar Tahun 2017, penyakit tuberkulosis merupakan penyakit menular langsung berbasis lingkungan yang menduduki peringkat kedua dengan jumlah kasus 1.071 setelah penyakit diare dengan jumlah kasus 1.076. Jumlah kasus BTA Positif pada Tahun 2017 di Kabupaten Kampar mencapai angka 1071 kasus, dengan jumlah penderita terbanyak terdapat di Kecamatan Tambang yaitu 78 Kasus. Pada Tahun 2018 jumlah kasus TB sebanyak 1079 kasus, dengan kasus tertinggi juga terjadi di Puskesmas Tambang dengan jumlah total 67 kasus dan 43 kasus baru, disusul oleh Puskesmas Siak Hulu I dengan jumlah 57 Kasus (Dinkes Kab.Kampar, 2018). Beradasarkan hal tersebut maka penelitian ini bertujuan untuk menganalisis dan besar risiko hubungan lingkungan fisik, sosial dan ekonomi dengan kejadian tuberkulosis paru di Kecamatan Tambang Kabupaten Kampar.

\section{METODE PENELITIAN}

Penelitian ini dilakukan di wilayah kerja Puskesmas Tambang Kecamatan Tambang, Kabupaten Kampar. Dengan pertimbangan jumlah penderita Tuberkulosis terbanyak se Kabupaten Kampar. Waktu penelitian dilakukan pada bulan Oktober 2019 s/d Desember 2019. Jenis penelitian ini adalah penelitian survei yang bersifat analitik dengan pendekatan case control untuk mengetahui faktor-faktor yang mempengaruhi kejadian penyakit TB Paru pada wilayah kerja Puskesmas Tambang Kecamatan Tambang Kabupaten Kampar. Dalam penelitian ini sekelompok kasus (kelompok yang menderita efek/penyakit yang sedang diteliti) dibandingkan dengan kelompok kontrol (kelompok yang tidak menderita efek/penyakit yang sedang diteliti).Responden yang berpartisipasi pada penelitian ini yaitu sebanyak 36 responden kasus dan 36 responden kontrol.Analisis data dilakukan dengan uji statistik chi square dan regresi logistik.

\section{HASIL DAN PEMBAHASAN}

Pada penelitian ini responden berjumlah 72 orang yang terdiri dari 36 orang kasus dan 36 kontrol. Karakteristik responden dalam penelitian ini dapat dilihat pada Tabel 1.

Tabel 1. Karakteristik Responden

\begin{tabular}{llll}
\hline No & Karakteristik & Frekuensi & Persentase (\%) \\
\hline $\mathbf{1}$ & Asal Desa & & \\
& Tarai Bangun & 12 & 16,7 \\
& Kualu & 10 & 13,9 \\
& Kuapan & 10 & 13,9 \\
& Rimbo Panjang & 10 & 13,9 \\
& Sungai Pinang & 6 & 8,3 \\
& Terantang & 10 & 13,9 \\
& Aur Sati & 6 & 8,3 \\
& Palung Raya & 4 & 5,6 \\
& Kualu Nenas & 4 & 5,6 \\
\hline
\end{tabular}




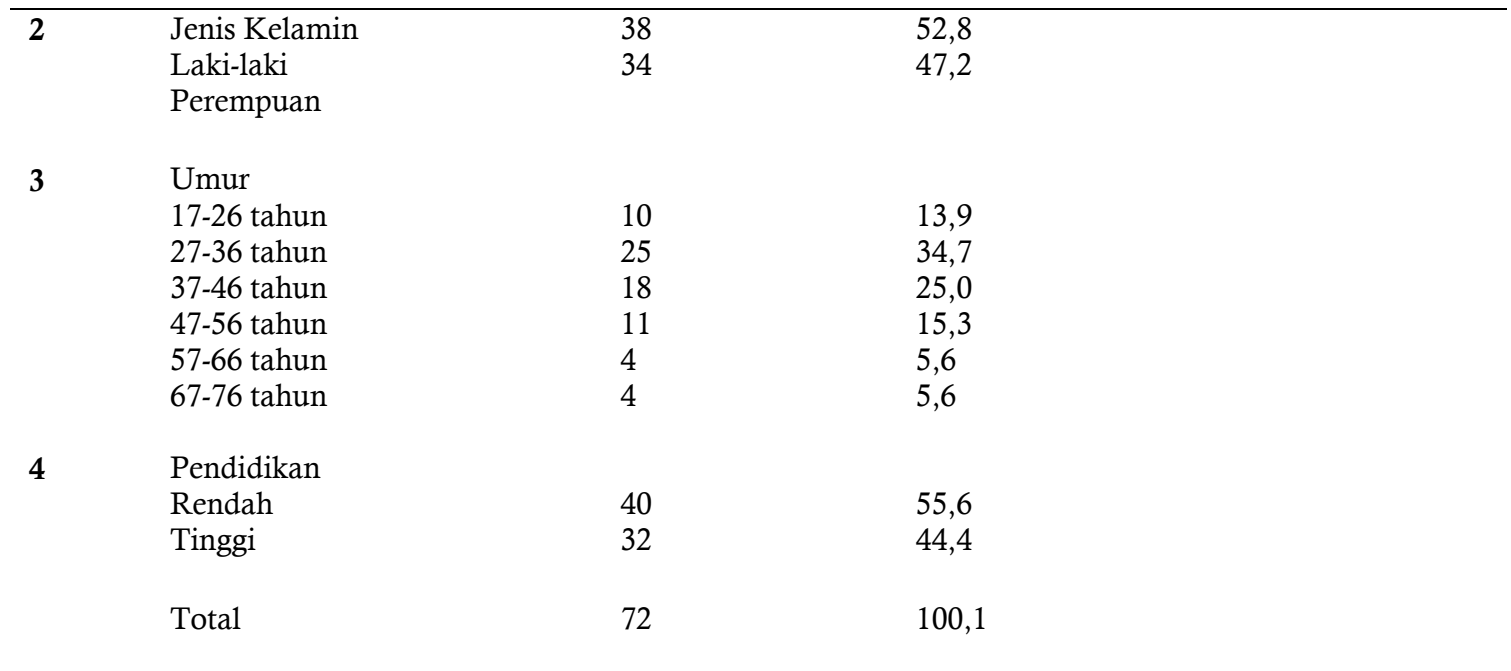

Berdasarkan Tabel 1 dapat dilihat bahwa Desa Tarai Bangun merupakan jumlah kasus tuberkulosis terbanyak di Puskesmas Kecamatan Tambang dengan jumlah kasus dan kontrol 12 orang (16,7\%). Desa Tarai Bangun merupakan wilayah dataran rendah yang dimanfaatkan sebagai lahan pertanian dan kawasan padat hunian. Sementara jumlah kasus terkecil adalah di desa Palung Raya dan Kualu Nenas dengan jumlah kasus dan kontrol sebanyak 4 orang $(5,6 \%)$. Berdasarkan jenis kelamin terdapat perbedaan distribusi responden di mana jumlah sampel laki-laki lebih banyak daripada jumlah sampel perempuan, yaitu laki-laki berjumlah 38 orang $(52,8 \%)$ sedangkan perempuan berjumlah 34 orang $(47,2 \%)$. Sebagian besar responden terbanyak berusia 27-34 tahun dengan jumlah 25 orang (34,7\%). Sementara pada kelompok umur 57-66 tahun dan 67-74 tahun memiliki proporsi paling sedikit dengan jumlah 4 0rang $(5,6 \%)$. Tabel 1 di atas menunjukkan bahwa proporsi tingkat pendidikan responden yang paling banyak adalah pendidikan yang rendah atau $<$ dari 9 tahun dengan jumlah 40 responden $(55,6 \%)$. Sedangkan proporsi tingkat pendidikan responden yang tinggi berjumlah 32 responden $(44,4 \%)$. Hal ini menunjukkan bahwa pendidikan seseorang berpengaruh terhadap kejadian penyakit TB paru. Pemahaman dan pengetahuan seseorang terhadap suatu penyakit tentu tidak lepas dari tingkat pendidikan yang dimilikinya.Karakteristik responden berdasarkan variabel yang diteliti dapat dilihat pada Tabel 2 berikut:

Tabel 2. Karakteristik Responden Berdasarkan Variabel

\begin{tabular}{|c|c|c|c|}
\hline No & Karakteristik & Frekuensi & Persentase $(\%)$ \\
\hline \multirow[t]{3}{*}{1} & Suhu & & \\
\hline & $\begin{array}{l}\text { Tidak memenuhi syarat } \\
\left(<18^{\circ} \mathrm{C}->30^{\circ} \mathrm{C}\right)\end{array}$ & 35 & 48,6 \\
\hline & $\begin{array}{l}\text { Memenuhi syarat } \\
\left(18^{\circ} \mathrm{C}-30^{\circ} \mathrm{C}\right)\end{array}$ & 37 & 51,4 \\
\hline \multirow[t]{3}{*}{2} & Kelembaban & & \\
\hline & $\begin{array}{l}\text { Tidak memenuhi syarat } \\
(<40 \% \text { atau }>60 \%)\end{array}$ & 34 & 47,2 \\
\hline & $\begin{array}{l}\text { Memenuhi syarat } \\
(40 \%-60 \%)\end{array}$ & 38 & 52,8 \\
\hline \multirow[t]{3}{*}{3} & Ventilasi & & \\
\hline & $\begin{array}{l}\text { Tidak memenuhi syarat } \\
(<10 \% \text { dari luas lantai) }\end{array}$ & 42 & 58,3 \\
\hline & $\begin{array}{l}\text { Memenuhi syarat } \\
(>10 \% \text { dari luas lantai) }\end{array}$ & 30 & 41,7 \\
\hline \multirow[t]{3}{*}{4} & Jenis Lantai & & \\
\hline & $\begin{array}{l}\text { Tidak memenuhi syarat } \\
\text { (Tanah) }\end{array}$ & 5 & 6,9 \\
\hline & $\begin{array}{l}\text { Memenuhi syarat } \\
\text { (Bukan tanah/semen/keramik) }\end{array}$ & 67 & 93,1 \\
\hline
\end{tabular}


SEHATI

Jurnal Kesehatan
Vol 1, No 1, Februari 2021, p. 6-15

e-ISSN : 2775-6963 | p-ISSN : 2775-6955
5

Pencahayaan

Tidak memenuhi syarat ( $<60$ lux)

Memenuhi syarat $(\geq 60$ lux $)$

6

Pengetahuan

Buruk

(Jawaban benar $<60 \%$ )

Baik

(Jawaban benar $>60 \%$ )

$7 \quad$ Kontak Serumah

Ada kontak

Tidak ada kontak

8

Perilaku Merokok

Merokok

Tidak merokok

9 Penghasilan Perbulan

Rendah

(Pendapatan satu bulan

< Rp. 2.718.724)

Tinggi

(Pendapatan satu bulan

$>$ Rp. 2.718.724)
61,1

38,9

55,6

44,4

48,6

51,4

45,8

54,2

47,2

100,0

Berdasarkan Tabel 2 responden yang memiliki rumah dengan suhu yang memenuhi syarat sebesar 37 responden $(51,4 \%)$ dan tidak memenuhi syarat sebesar 35 responden (48,6\%), Responden yang memiliki rumah dengan kelembaban yang memenuhi syarat adalah sebesar 38 responden $(52,8 \%)$ sedangkan responden yang memiliki rumah dengan kelembaban yang tidak memenuhi syarat adalah sebesar 34 responden (42,7\%), sebagian besar responden memiliki ventilasi rumah yang tidak memenuhi syarat yaitu sebesar 42 responden (58,3\%), sedangkan responden yang memiliki ventilasi rumah yang memenuhi syarat sebanyak 30 responden $(41,7 \%)$, sebagian besar responden dengan jenis lantai rumah yang memenuhi syarat yaitu sebesar 67 responden $(93,1 \%)$, sedangkan responden yang memiliki rumah dengan jenis lantai yang tidak memenuhi syarat sebanyak 5 responden $(6,9 \%)$, Responden yang memiliki rumah dengan pencahayaan yang tidak memenuhi syarat adalah sebesar 44 responden $(61,1 \%)$ sedangkan responden yang memiliki rumah dengan pencahayaan yang memenuhi syarat adalah sebesar 28 responden (38,9\%), Berdasarkan Tabel 2 dapat dilihat bahwa responden yang memiliki pengetahuan yang buruk adalah sebanyak 40 responden $(55,6 \%)$ sedangkan responden yang memiliki pengetahuan yang baik sebesar 32 responden $(44,4 \%)$, responden yang ada melakukan kontak serumah adalah sebanyak 35 responden (48,6\%) sedangkan responden yang tidak ada melakukan kontak serumah adalah sebanyak 37 responden $(51,4 \%)$, Pada peneltian, terdapat 33 orang responden yang merokok (45,8\%) dan responden yang tidak merokok sebanyak 39 orang responden $(54,2 \%)$. Berdasarkan Tabel 2 dapat dilihat bahwa responden yang memiliki penghasilan perbulan rendah atau $<$ Rp.2.718.724 adalah sebesar 34 responden (47,2\%) sedangkan responden yang memiliki penghasilan perbulan tinggi atau > Rp.2.718.724 adalah sebesar 38 responden $(52,8 \%)$. 
Tabel 3. Hubungan antara Lingkungan Fisik Rumah dengan Kejadian Tuberkulosis Paru di Puskesmas Kecamatan Tambang Kabupaten Kampar

\begin{tabular}{|c|c|c|c|c|c|c|c|c|c|}
\hline \multirow{3}{*}{ Variabel } & \multicolumn{4}{|c|}{ Responden } & \multirow{2}{*}{\multicolumn{2}{|c|}{ Total }} & \multirow{3}{*}{$\begin{array}{l}\mathrm{P} \\
\text { Value }\end{array}$} & \multirow{3}{*}{$\begin{array}{l}\text { Odd } \\
\text { Ratio }\end{array}$} & \multirow{3}{*}{$\begin{array}{l}\mathrm{CI} \\
95 \%\end{array}$} \\
\hline & \multicolumn{2}{|c|}{ Kasus } & \multicolumn{2}{|c|}{ Kontrol } & & & & & \\
\hline & $\mathbf{F}$ & $\%$ & $\mathrm{~F}$ & $\%$ & $\mathrm{~F}$ & $\%$ & & & \\
\hline \multicolumn{10}{|l|}{ Suhu } \\
\hline $\begin{array}{l}\text { Tidak } \\
\text { memenuhisyarat }\end{array}$ & 23 & 63,9 & 12 & 33,3 & 35 & 48,6 & \multirow[t]{2}{*}{0,018} & \multirow[t]{2}{*}{3,538} & \multirow{2}{*}{$\begin{array}{l}1,340- \\
9,343\end{array}$} \\
\hline $\begin{array}{l}\text { Memenuhi } \\
\text { syarat }\end{array}$ & 13 & 36,1 & 24 & 66,7 & 37 & 51,4 & & & \\
\hline \multirow{2}{*}{$\begin{array}{l}\text { Kelembaban } \\
\text { Tidak memenuhi } \\
\text { syarat } \\
\text { Memenuhi syarat }\end{array}$} & 24 & 66,7 & 10 & 27,8 & 34 & 42,7 & \multirow[b]{2}{*}{0,002} & \multirow{2}{*}{5,200} & \multirow{2}{*}{$\begin{array}{l}1,901- \\
14,22 \\
0\end{array}$} \\
\hline & 12 & 33,3 & 26 & 72,2 & 38 & 52,8 & & & \\
\hline \multicolumn{10}{|l|}{ Ventilasi } \\
\hline $\begin{array}{l}\text { Tidak memenuhi } \\
\text { syarat }\end{array}$ & 27 & 75,0 & 15 & 41,7 & 42 & 58,3 & \multirow[t]{2}{*}{0,009} & \multirow[t]{2}{*}{4,200} & 11,46 \\
\hline Memenuhi syarat & 9 & 25,0 & 21 & 58,3 & 30 & 41,7 & & & \\
\hline \multicolumn{9}{|l|}{ Jenis Lantai } & \multirow{3}{*}{$\begin{array}{l}0,464- \\
41,22 \\
5\end{array}$} \\
\hline $\begin{array}{l}\text { Tidak memenuhi } \\
\text { syarat }\end{array}$ & 4 & 11,1 & 1 & 2,8 & 5 & 6,9 & 0,354 & 4,375 & \\
\hline Memenuhi syarat & 32 & 88,9 & 35 & 97,2 & 67 & 93,1 & & & \\
\hline \multicolumn{10}{|l|}{ Pencahayaan } \\
\hline $\begin{array}{l}\text { Tidak memenuhi } \\
\text { syarat }\end{array}$ & 28 & 77,8 & 16 & 44,4 & 44 & 61,1 & & \multirow{3}{*}{4,375} & \multirow{3}{*}{$\begin{array}{l}1,571- \\
12,18 \\
7\end{array}$} \\
\hline Memenuhi syarat & 8 & 22,2 & 20 & 55,6 & 28 & 38,9 & 0,008 & & \\
\hline Total & 36 & 100 & 36 & 100 & 72 & 100 & & & \\
\hline
\end{tabular}

Dari Tabel 3 dapat terlihat bahwa pada kelompok kasus terdapat 23 responden (63,9\%) dengan suhu rumah yang tidak memenuhi syarat dan 13 responden $(36,1 \%)$ dengan suhu rumah yang memenuhi syarat. Sedangkan pada kelompok kontrol ada 12 responden $(33,3 \%)$ dengan suhu rumah yang tidak memenuhi syarat dan 24 responden $(66,7 \%)$ dengan suhu rumah yang memenuhi syarat. Hasil uji statistik chi square, diperoleh $p$ value $=0,018$ artinya $p$ value kecil dari 0,05 dengan demikian menunjukan bahwa ada hubungan yang signifikan antara suhu dengan kejadian Tuberkulosis paru. Nilai Odds Ratio $(\mathrm{OR})=3,538$ dengan nilai Confidence Interval $95 \%(\mathrm{CI})=1,340-9,343$ artinya responden dengan suhu rumah tidak memenuhi syarat $<18^{\circ} \mathrm{C}->30^{\circ} \mathrm{C}$ maka 3,53 kali berpeluang untuk menderita tuberkulosis paru daripada responden dengan suhu rumah yang memenuhi syarat $18^{\circ} \mathrm{C}-30^{\circ} \mathrm{C}$. Hal ini sejalan dengan penelitian yang di lakukan oleh Muslimah (2018) di Surabaya menunjukkan bahwa adanya hubungan yang signifikan antara suhu dengan kejadian tuberkulosis dengan hasil uji statistik chi square, diperoleh $p$ value $=0,000$.

Berdasarkan kelembaban pada kelompok kasus ada 24 responden (66,7\%) dengan kelembaban rumah tidak memenuhi syarat dan 12 responden $(33,3 \%)$ dengan kelembaban rumah memenuhi syarat. Sementara pada kelompok kontrol ada 10 responden $(27,8 \%)$ dengan kelembaban rumah tidak memenuhi syarat dan 26 responden $(72,2 \%)$ dengan kelembaban rumah memenuhi syarat. Hasil uji statistik chi square, diperoleh $p$ value $=0,002$ artinya $p$ value kecil dari 0,05 dengan demikian menunjukan bahwa ada hubungan yang signifikan antara kelembaban dengan kejadian Tuberkulosis Paru. Nilai Odds Ratio (OR) = 5,200 dengan nilai Confidence Interval 95\% $(\mathrm{CI})=1,901-14,220$ artinya responden dengan kelembaban rumah lebih dari $60 \% \mathrm{Rh}, 5$ kali berpeluang untuk menderita Tuberkulosis Paru daripada responden dengan kelembaban rumah kurang dari $60 \%$ Rh.Penelitian ini sejalan dengan penelitian yang dilakukan oleh Siregar (2012) di Subussalam, menyatakan bahwa hasil penelitian ada hubungan yang signifikan antara kelembaban dengan kejadian tuberkulosis paru dengan nilai $p$ value $=0,001$ dan risiko kelembaban ruangan yang tidak baik terkena tuberkulosis paru 84,3 kali dibandingkan dengan rumah yang memiliki kelembaban yang baik.

Dari Tabel 3 dapat terlihat bahwa pada kelompok kasus terdapat 27 responden $(75,0 \%)$ dengan ventilasi rumah yang tidak memenuhi syarat dan 9 responden $(25,0 \%)$ dengan ventilasi rumah yang 


\section{SEHATI}

Jurnal Kesehatan

Vol 1, No 1, Februari 2021, p. 6-15

e-ISSN : 2775-6963 | p-ISSN : 2775-6955

memenuhi syarat. Sedangkan pada kelompok kontrol ada 15 responden $(41,7 \%)$ dengan ventilasi rumah yang tidak memenuhi syarat dan 21 responden $(58,3 \%)$ memiliki ventilasi rumah yang memenuhi syarat. Hasil uji statistik chi square, diperoleh $p$ value $=0,009$ artinya $p$ value kecil dari 0,05 dengan demikian menunjukan bahwa ada hubungan yang signifikan antara ventilasi dengan kejadian Tuberkulosis paru. Nilai Odds Ratio $(\mathrm{OR})=4,200$ dengan nilai Confidence Interval 95\% $(\mathrm{CI})=1,539-11,463$ artinya responden dengan ventilasi rumah tidak memenuhi syarat $>10 \%$ dari luas lantai maka 4,20 kali berpeluang untuk menderita Tuberkulosis paru dari pada responden dengan ventilasi rumah yang memenuhi syarat $>10 \%$ dari luas lantai.

Berdasarkan jenis lantai, pada kelompok kasus ada 4 responden $(11,1 \%)$ dengan jenis lantai rumah tidak memenuhi syarat dan 32 responden $(88,9 \%)$ dengan jenis lantai rumah memenuhi syarat. Sedangkan pada kelompok kontrol ada 1 responden $(2,8 \%)$ dengan jenis lantai rumah tidak memenuhi syarat dan 35 responden $(97,2 \%)$ dengan jenis lantai rumah memenuhi syarat. Hasil uji statistik chi square, diperoleh $p$ value $=0,354$ artinya $p$ value lebih besar dari 0,05 dengan demikian menunjukan bahwa tidak ada hubungan yang signifikan antara jenis lantai dengan kejadian Tuberkulosis Paru.

Berdasarkan pencahayaan, pada kelompok kasus terdapat 28 responden $(77,8 \%)$ dengan pencahayaan rumah yang tidak memenuhi syarat dan 8 responden $(22,2 \%)$ dengan pencahayaan rumah yang memenuhi syarat. Sedangkan pada kelompok kontrol ada 16 responden $(44,4 \%)$ dengan pencahayaan rumah yang tidak memenuhi syarat dan 20 responden $(55,6 \%)$ memiliki pencahayaan rumah yang memenuhi syarat. Hasil uji statistik chi square, diperoleh $p$ value $=0,008$ artinya $p$ value kecil dari 0,05 dengan demikian menunjukan bahwa ada hubungan yang signifikan antara pencahayaan dengan kejadian Tuberkulosis paru. Nilai Odds Ratio (OR) $=4,375$ dengan nilai Confidence Interval 95\% $(\mathrm{CI})=1,571-12,187$ artinya responden dengan pencahayaan rumah tidak memenuhi syarat $<60$ lux maka 4,37 kali berpeluang untuk menderita Tuberkulosis paru dari pada responden dengan pencahayaan rumah yang memenuhi syarat $\geq 60$ lux.

Tabel 4. Hubungan antara Lingkungan Sosial dengan Kejadian Tuberkulosis Paru Di Puskesmas Kecamatan Tambang Kabupaten Kampar

\begin{tabular}{|c|c|c|c|c|c|c|c|c|c|}
\hline \multirow{3}{*}{ Variabel } & \multicolumn{4}{|c|}{ Responden } & \multirow{2}{*}{\multicolumn{2}{|c|}{ Total }} & \multirow{3}{*}{$\begin{array}{l}\mathrm{P} \\
\text { Value }\end{array}$} & \multirow{3}{*}{$\begin{array}{l}\text { Odd } \\
\text { Ratio }\end{array}$} & \multirow{3}{*}{$\begin{array}{l}\text { CI } \\
\text { v95\% }\end{array}$} \\
\hline & \multicolumn{2}{|c|}{ Kasus } & \multicolumn{2}{|c|}{ Kontrol } & & & & & \\
\hline & $\mathrm{F}$ & $\%$ & $\mathrm{~F}$ & $\%$ & $\mathrm{~F}$ & $\%$ & & & \\
\hline \multicolumn{10}{|l|}{ Pengetahuan } \\
\hline Buruk & & & & & & & \multirow{4}{*}{0,009} & \multirow{4}{*}{4,086} & \multirow{4}{*}{$1,518-11,000$} \\
\hline Baik & $\begin{array}{l}26 \\
10\end{array}$ & 27,8 & $\begin{array}{l}14 \\
22\end{array}$ & $\begin{array}{l}38,9 \\
61,1\end{array}$ & $\begin{array}{l}40 \\
32\end{array}$ & $\begin{array}{l}55,6 \\
44,4\end{array}$ & & & \\
\hline Total & 36 & 100 & 36 & 100 & 72 & 100 & & & \\
\hline \multicolumn{7}{|l|}{ Kontak serumah } & & & \\
\hline Ada & 24 & 66,7 & 11 & 30,6 & 35 & 48,6 & \multirow{3}{*}{0,005} & \multirow{3}{*}{4,545} & \multirow{3}{*}{$1,686-12,251$} \\
\hline Tidak ada & 12 & 33,3 & 25 & 69,4 & 37 & 51,4 & & & \\
\hline Total & 36 & 100 & 36 & 100 & 72 & 100 & & & \\
\hline \multicolumn{10}{|c|}{ Perilaku merokok } \\
\hline Merokok & 23 & 63,9 & 10 & 27,8 & 33 & 45,8 & \multirow[t]{3}{*}{0,005} & \multirow[t]{3}{*}{4,600} & \multirow{3}{*}{$1,697-12,469$} \\
\hline Tidak merokok & 13 & 36,1 & 26 & 72,2 & 39 & 54,2 & & & \\
\hline Total & 36 & 100 & 36 & 100 & 72 & 100 & & & \\
\hline
\end{tabular}

Dari Tabel 4 dapat terlihat bahwa pada kelompok kasus terdapat 26 responden $(72,2 \%)$ dengan pengetahuan yang buruk dan 10 responden $(27,8 \%)$ dengan pengetahuan yang baik. Sementara pada kelompok kontrol ada 14 responden $(38,9 \%)$ dengan pengetahuan yang buruk dan 22 responden $(61,1 \%)$ dengan pengetahuan yang baik. Hasil uji statistik chi square, diperoleh $p$ value $=0,009$ artinya $p$ value kecil dari 0,05 dengan demikian menunjukan bahwa ada hubungan yang signifikan antara pengetahuan dengan kejadian Tuberkulosis paru. Nilai Odds Ratio $(\mathrm{OR})=4,086$ dengan nilai Confidence Interval $95 \%(\mathrm{CI})=$ 1,518-11,000 artinya responden dengan pengetahuan yang buruk jika jawaban benar $<60 \%$ maka 4,086 kali berpeluang untuk menderita Tuberkulosis paru dari pada responden dengan pengetahuan yang baik dengan jawaan benar $>60 \%$.Penelitian ini sejalan dengan yang dilakukan oleh Damayanti, dkk (2017) di wilayah kerja puskesmas Liukang. Hasil uji statistik menggunakan uji chi square didapat nilai pvalue = $0,034$ ( $p$ value $<0,05)$ yang berarti ada hubungan antara tingkat pengetahuan dengan kejadian TB Paru.

Berdasarkan kontak serumah dapat terlihat bahwa pada kelompok kasus terdapat 24 responden $(66,7 \%)$ yang ada kontak serumah dengan penderita lain dan 12 responden $(33,3 \%)$ yang tidak ada kontak 


\section{SEHATI}

Jurnal Kesehatan

Vol 1, No 1, Februari 2021, p. 6-15

e-ISSN : 2775-6963 | p-ISSN : 2775-6955

serumah dengan penderita lain. Sedangkan pada kelompok kontrol ada 11 responden (30,6\%) yang ada kontak serumah dengan penderita dan 25 responden $(61,1 \%)$ yang tidak ada kontak serumah dengan penderita. Hasil uji statistik chi square, diperoleh $p$ value $=0,005$ artinya $p$ value kecil dari 0,05 dengan demikian menunjukan bahwa ada hubungan yang signifikan antara kontak serumah dengan kejadian Tuberkulosis paru. Nilai Odds Ratio (OR) $=4,545$ dengan nilai Confidence Interval 95\% $(\mathrm{CI})=1,686-12,251$ artinya responden dengan adanya kontak serumah maka 4,545 kali berpeluang untuk menderita Tuberkulosis paru dari pada responden dengan tidak adanya kontak serumah.Penelitian ini sejalan dengan penelitian yang dilakukan oleh Oktavia (2016) dengan hasil penelitian menunjukkan bahwa ada hubungan yang signifikan antara kontak dengan penderita TB paru berisiko sebesar 4,7 kali lebih besar terkena TB Paru dibandingkan dengan yang tidak kontak dengan penderita TB paru, dengan nilai $p$ value $=0,02$ ( $p$ value $<0,05$ ) artinya ada hubungan yang bermakna secara statistik antara kontak dengan pasien TB paru dengan kejadian TB paru.

Berdasarkan perilaku merokok dapat terlihat bahwa pada kelompok kasus terdapat 23 responden $(63,9 \%)$ yang memiliki perilaku merokok dan 13 responden $(36,1 \%)$ yang tidak merokok. Sedangkan pada kelompok kontrol ada 10 responden $(27,8 \%)$ yang memiliki perilaku merokok dan 26 responden $(72,2 \%)$ yang tidak merokok. Hasil uji statistik chi square, diperoleh $p$ value $=0,005$ artinya $p$ value kecil dari 0,05 . Dengan demikian menunjukan bahwa ada hubungan yang signifikan antara perilaku merokok dengan kejadian Tuberkulosis paru. Nilai Odds Ratio $(\mathrm{OR})=4,600$ dengan nilai Confidence Interval $95 \%(\mathrm{CI})=$ 1,697-12,469 artinya responden dengan perilaku merokok maka 4,600 kali berpeluang untuk menderita Tuberkulosis paru dari pada responden yang tidak merokok.Penelitian ini sejalan dengan penelitian yang dilakukan oleh Anggraeni (2015) di Malang dengan hasil uji statistik menggunakan uji chi square didapat nilai $p$ value $=0,0001$ ( $p$ value $<0,05$ ) yang berarti ada hubungan antara perilaku merokok dengan kejadian TB Paru.Penelitian ini tidak sejalan dengan penelitan yang dilakukan oleh Sejati (2014) didapat nilai pvalue $=0,1000$ ( $p$ value $>0,05)$ yang berarti tidak ada hubungan antara perilaku merokok dengan kejadian TB Paru.

Tabel 5. Hubungan Ekonomi dengan Kejadian Tuberkulosis Paru di Puskesmas Kecamatan Tambang Kabupaten Kampar

\begin{tabular}{|c|c|c|c|c|c|c|c|c|c|}
\hline \multirow{3}{*}{ Variabel } & \multicolumn{4}{|c|}{ Responden } & \multirow{2}{*}{\multicolumn{2}{|c|}{ Total }} & \multirow{3}{*}{$\begin{array}{l}\mathrm{P} \\
\text { Value }\end{array}$} & \multirow{3}{*}{$\begin{array}{l}\text { Odd } \\
\text { Ratio }\end{array}$} & \multirow{3}{*}{ CI 95\% } \\
\hline & \multicolumn{2}{|c|}{ Kasus } & \multicolumn{2}{|c|}{ Kontrol } & & & & & \\
\hline & $\mathrm{F}$ & $\%$ & $\mathrm{~F}$ & $\%$ & $\mathrm{~F}$ & $\%$ & & & \\
\hline \multicolumn{10}{|c|}{ Penghasilan } \\
\hline Rendah & & 61.1 & 12 & 33.3 & 34 & 47.2 & \multirow{3}{*}{0,034} & \multirow{3}{*}{3,143} & \multirow{3}{*}{$\begin{array}{l}1,199 \\
8,241\end{array}$} \\
\hline Tinggi & $\begin{array}{l}22 \\
14\end{array}$ & 38,9 & 24 & $\begin{array}{l}3,0 \\
66,7\end{array}$ & 38 & 52,8 & & & \\
\hline Total & 36 & 100 & 36 & 100 & 72 & 100 & & & \\
\hline
\end{tabular}

Dari Tabel 5 dapat terlihat bahwa pada kelompok kasus terdapat 22 responden $(61,1 \%)$ dengan penghasilan yang rendah dan 14 responden (38,9\%) dengan penghasilan yang tinggi. Sementara pada kelompok kontrol ada 12 responden $(33,3 \%)$ dengan penghasilan yang rendah dan 24 responden $(66,7 \%)$ dengan penghasilan yang tinggi. Hasil uji statistik chi square, diperoleh $p$ value $=0,034$ artinya $p$ value kecil dari 0,05 dengan demikian menunjukan bahwa ada hubungan yang signifikan antara penghasilan dengan kejadian Tuberkulosis paru. Nilai Odds Ratio $(\mathrm{OR})=3,143$ dengan nilai Confidence Interval $95 \%(\mathrm{CI})=$ 1,199-8,241 artinya responden dengan penghasilan yang rendah jika penghasilan perbulan kurang dari Rp. 2.718.724 maka 3,143 kali berpeluang untuk menderita Tuberkulosis paru dari pada responden dengan responden yang berpenghasilan $\geq$ Rp. 2.718.724.Penelitian ini sejalan dengan penelitian yang dilakukan oleh Yuniar (2017) di Kabupaten Kebumen dengan hasil uji statistik menggunakan uji chi square didapat nilai $p$ value $=0,005$ ( $p$ value $<0,05)$ yang berarti ada hubungan antara penghasilan dengan kejadian TB Paru. Berdasarkan hasil analisis besar risiko didapatkan nilai Odds Ratio (OR) sebesar 4,421 artinya responden yang memiliki penghasilan yang rendah 4,421 kali lebih berisiko menderita TB Paru dibandingkan dengan responden yang memiliki penghasilan yang tingi. 
Tabel 6. Model akhir pemodelan multivariat variabel dominan terhadap Kejadian Tuberkulosis Paru di Puskesmas Kecamatan Tambang Kabupaten Kampar

\begin{tabular}{lllllllr}
\hline & B & S.E. & Wald & df & \multicolumn{2}{l}{ Sig. } & \multicolumn{2}{l}{$\operatorname{Exp(B)}$} \\
\hline${\text { Step } 1^{\mathrm{a}}}^{\mathrm{a}}$ & Suhu & 1.746 & 0,887 & 3,875 & 1 & 0.049 & 5.731 \\
& Kelembaban & 2.182 & 0,911 & 5,737 & 1 & 0.017 & 8.860 \\
& Ventilasi & 1.439 & 0,812 & 3,142 & 1 & 0.076 & 4.217 \\
& Pencahayaan & 2.023 & 0,851 & 5,649 & 1 & 0.017 & 7.564 \\
Pengetahuan & 1.610 & 0,789 & 4,165 & 1 & 0.041 & 5.002 \\
Kontak serumah & 1.563 & 0,874 & 3,199 & 1 & 0.074 & 4.771 \\
& Penghasilan & 1.322 & 0,807 & 2,681 & 1 & 0.102 & 3.751 \\
& Perilaku merokok & 2.013 & 0,842 & 5,721 & 1 & 0.017 & 7.484 \\
\hline & Constant & -7.123 & 1,916 & 13,822 & 1 & 0,000 & 0,001 \\
\hline
\end{tabular}

Berdasarkan Tabel 6 dapat diketahui bahwa variabel yang paling dominan mempengaruhi kejadian tuberkulosis paru adalah kelembaban dengan nilai p 0,017 dan OR sebesar 8,860 artinya kelembaban yang tidak memenuhi syarat $<40 \%$ atau $>60 \%$ berpeluang mempengaruhi kejadian tuberkulosis paru 8,860 kali lebih besar dibandingkan dengan kelembaban yang memenuhi syarat $40 \%-70 \%$. Hasil penelitian ini sejalan dengan penelitian yang dilakukan oleh Anggraeni (2015) yaitu ada hubungan antara kelembaban dengan kejadian tuberkulosis paru. Besarnya risiko dapat dilihat dari nilai Odds Ratio (OR), OR=6,417 menunjukkan bahwa seseorang yang tinggal di rumah dengan tingkat kelembaban yang tidak memenuhi syarat ( $<40 \%$ dan lebih $>60 \%$ ) berisiko 6,4 kali lebih besar dibandingkan dengan seseorang yang tinggal di rumah dengan intensitas yang memenuhi syarat kesehatan. berikut:

Berdasarkan Tabel 6 rumus matematis yang terbentuk dari analisis regresi logistik berganda sebagai

$$
\begin{gathered}
\mathrm{Y}=7,123+1,746 \mathrm{X} 1+2,182 \mathrm{X} 2+1,439 \mathrm{X} 3+2,023 \mathrm{X} 4+1,610 \mathrm{X} 5+1,563 \mathrm{X} 6+ \\
1,322 \mathrm{X} 7+2,013 \mathrm{X} 8
\end{gathered}
$$

Melalui persamaan tersebut dapat dibuat suatu contoh kasus, bahwa bila terdapat 1 kejadian tuberkulosis paru di Puskesmas Tambang dipengaruhi sebesar 1,74 kali faktor risiko suhu rumah responden, 2,18 kali faktor risiko kelembaban rumah responden, 1,43 kali faktor risiko luas ventilasi rumah responden, 2 kali faktor risiko pencahayaan rumah responden, 1,61 kali faktor risiko pengetahuan responden, 1,53 kali faktor risiko kontak serumah responden, 1,32 kali faktor risiko penghasilan responden, serta 2 kali faktor risiko perilaku merokok responden.

Dengan demikian maka untuk mengetahui peluang kemungkinan penyebab kejadian tuberkulosis paru di Puskesmas Tambang Kabupaten Kampar dapat dilihat melalui persamaan regresi logistik berganda sebagai berikut :

$$
p=\frac{1}{1+e^{-\left(\mathrm{a}+\mathrm{B}_{I_{x} I^{+} \mathrm{B}_{2 x} x^{2}}\right.}}
$$

Keterangan :
$\mathrm{B} 1, \mathrm{~B} 2$
$=$ Konstanta
$\mathrm{X} 1, \mathrm{X} 2, \mathrm{Xn}$
$=$ Koefisien regresi variabel bebas
$\mathrm{p}$
= Variabel predictor yang pengaruhnya diteliti
$=$ Probabilitas untuk terjadinya peristiwa dari variabel tergantung 
Berdasarkan nilai dari masing-masing variabel yang telah dihitung melalui uji statistik regresi logistik maka diperoleh hasil perhitungan dari persamaan sebagai berikut :

\section{1}

$$
\begin{aligned}
p= & \frac{-(-7,123+1,746 \text { suhu }+2,182 \text { kelembaban }+1,439 \text { ventilasi }+2,023 \text { pencahayaan }}{+1,610 \text { pengetahuan }+1,563 \text { kontak serwmah }+1,322 \text { penghasilan perbulan }} \\
p= & \frac{1}{+2,013 \text { perilaku merokok })} \\
p= & \frac{1}{1+2,72^{-(-7,123+1,746+2,182+1,439+2,023+1,610+1,563+1,322+2,013)}} \\
p= & \frac{1}{1+0,0011} \\
& p=0,99(99 \text { Persen })
\end{aligned}
$$

Berdasarkan hasil perhitungan persamaan dapat disimpulkan bahwa jika seseorang memiliki faktor risiko suhu, faktor risiko kelembaban, faktor risiko ventilasi, faktor risiko pencahayaan, faktor risiko pengetahuan, faktor risiko kontak serumah, faktor risiko penghasilan perbulan dan faktor risiko perilaku merokok, maka akan mempunyai peluang untuk menderita tuberkulosis paru sebesar 99 persen (dengan nilai probabilitas sebesar 0,99 ).

Untuk mewujudkan rumah yang sehat, masyarakat yang tinggal di Kecamatan Tambang Kabupaten Kampar, dapat berpedoman pada pengelolaan lingkungan rumah sehat yang telah diatur sesuai dengan peraturan Kementerian Kesehatan Indonesia, yaitu :

Menurut KepMenkes RI No.829/Menkes/SK/VII/1999, jenis lantai yang memenuhi syarat kesehatan adalah yang kedap air dan mudah dibersihkan, seperti jenis lantai yang terbuat dari plester, ubin, semen, porselen atau keramik, sedangkan jenis lantai yang tidak memenuhi syarat kesehatan adalah tidak kedap air seperti jenis lantai tanah, papan, dan lontar. Jenis lantai papan atau panggung dapat menyebabkan kenaikan kelembaban rumah karena papan bukan bahan kedap air dan pengaruh kelembaban tanah. Untuk mencegah terjadinya kelembaban pada rumah dengan jenis lantai papan, perlu dilapisi dengan tikar karet yang berfungsi sebagai alas kedap air sehingga mampu melindungi dari rembesan air dan kelembaban. Lantai tanah sebaiknya tidak digunakan lagi, sebab bila musim hujan akan lembab sehingga dapat meningkatkan risiko penyebaran tuberkulosis pada penghuninya. Karena itu, perlu dilapisi dengan lapisan yang kedap air seperti semen, dipasang tegel, keramik.

Peraturan Menteri Kesehatan RI No.1077 Tahun 2011 tentang pedoman penyehatan udara dalam ruang rumah menyatakan bahwa suhu udara yang dipersyaratkan berkisar antara $18-30^{\circ} \mathrm{C}$. suhu yang tidak sesuai syarat berpotensi meningkatkan keadaan yang kondusif bagi bakteri tersebut untuk hidup dan juga berpotensi meningkatkan penularan penyakit TB Paru. Upaya penyehatan yang dapat dilakukan oleh masyarakat adalah dengan menambah ventilasi mekanik atau buatan.

Keputusan Menteri Kesehatan RI Nomor : No.1077 /Menkes/Per/V/2011 kelembaban udara berkisar antara 40\% - 70\%. Kuman TB Paru akan cepat mati bila terkena sinar matahari langsung, tetapi dapat bertahan hidup selama beberapa jam di tempat yang gelap dan lembab.

Berdasarkan PerMenKes RI No.1077 /Menkes/Per/V/2011 ventilasi yang memenuhi syarat adalah $>10 \%$ dari luas lantai. Upaya yang dapat dilakukan adalah dengan menambah jumlah ventilasi pada rumah. Sementara upaya sederhana yang dapat dilakukan adalah dengan membuka pintu dan jendela setiap hari agar terjadinya pertukaran aliran udara secara terus menerus untuk membebaskan udara ruangan dari bakteri tuberkulosis, serta tidak menutup lubang ventilasi dengan plastik ataupun lemari.

Berdasarkan PerMenKes RI No.1077 /Menkes/Per/V/2011 banyaknya sinar matahari yang masuk ke dalam rumah yang memenuhi syarat adalah $>60$ lux. Masyarakat dapat mengupayakan agar sinar 
matahari masuk ke dalam rumah dengan memasang genteng kaca plastik agar rumah tidak gelap dan mengurangi kelembaban di dalam rumah.

\section{KESIMPULAN}

Berdasarkan faktor lingkungan fisik, ada pengaruh yang signifikan antara suhu, kelembaban, ventilasi dan pencahayaan terhadap kejadian tuberkulosis paru. Tidak ada pengaruh yang signifikan antara jenis lantai terhadap kejadian tuberkulosis paru di Puskesmas Tambang Kabupaten Kampar. Berdasarkan faktor lingkungan sosial, ada pengaruh yang signifikan antara pengetahuan, kontak serumah, dan perilaku merokok terhadap kejadian tuberkulosis paru di Puskesmas Tambang Kabupaten Kampar. Berdasarkan faktor ekonomi, ada pengaruh yang signifikan antara penghasilan terhadap kejadian tuberkulosis paru di Puskesmas Tambang Kabupaten Kampar.Berdasarkan faktor risiko yang paling dominan, faktor kelembaban merupakan faktor risiko yang paling dominan terhadap kejadian tuberkulosis paru di Puskesmas Tambang Kabupaten Kampar.Untuk mengurangi risiko angka kejadian tuberkulosis dapat dilakukan pengelolaan lingkungan yang sesuai dengan peraturan Kementrian Kesehatan Republik Indonesia.

\section{UCAPAN TERIMAKASIH}

Ucapan terima kasih penulis sampaikan kepada pihak Puskesmas Tambang Kabupaten Kampar yang telah memberikan data dan informasi tentang pasien Tuberkulosis Paru, kepada seluruh aparatur desa Kecamatan Tambang serta semua pihak yang telah membantu terlaksananya penelitian ini di lapangan.

\section{DAFTAR PUSTAKA}

Achmadi, U. 2010. Manajemen Penyakit Berbasis Wilayah. Universitas Indonesia. Depok.

Anggraeni, K. 2015. Hubungan Kualitas Lingkungan Fisik Rumah dan Perilaku Kesehatan dengan Kejadian TB Paru di Wilayah Kerja Puskesmas Gondanglegi Kecamatan Gondanglegi Kabupaten Malang. Jurnal Kesehatan Masyarakat (E-Journal), Vol 3 No 1.

Dinkes Kab.Kampar (Dinas Kesehatan Kabupaten Kampar). 2018. Profil Kesehatan Kabupaten Kampar Tahun 2018. Kampar.

Direktorat Jenderal Pengendalian Penyakit dan Penyehatan Lingkungan. 2011. Strategi Nasional Pengendalian TB di Indonesia 2010-2014. Jakarta.

Fitriani, E. 2013. Faktor Risiko yang Berhubungan dengan Kejadian Tuberkulosis Paru (Studi Kasus di Puskesmas Ketanggungan Kabupaten Brebes). Unnes Journal of Public Health Epidomiology Vol 2 No 1.

Kemenkes RI (Kementerian Kesehatan Republik Indonesia). 1999. Keputusan Menteri Kesehatan Republik Indonesia Nomor 829/Menkes/SK/VII/1999 tentang Persyaratan Kesehatan Perumahan. Depkes RI. Jakarta 